\title{
FRAY LUIS DE GRANADA Y PETRARCA
}

Ana María Freire López

$U N E D$

Al leer a fray Luis de Granada, cerca ya del cuarto centenario de su muerte, llama la atención el descuido en que se encuentran las ediciones sobre uno de los mejores prosistas castellanos. Muchos aspectos de su obra todavía no han sido objeto de investigación, si exceptuamos su relación con el erasmismo y con la Inquisición, la autoría de alguna de sus obras, y algún que otro aspecto temático o retórico de sus escritos.

Por lo que yo conozco, nadie ha señalado su posible relación con Petrarca. Una reciente lectura de la Guía de pecadores me ha hecho descubrirlo entre sus páginas, y sería ingratitud no confesar que fue La Celestina quien me sirvió de medianera.

No pretendo hablar del posible "petrarquismo" -tal como se entiende el término- en la obra de fray Luis. Sí quiero, sin embargo, señalar la coincidencia, prácticamente literal, de un fragmento, que quizá pueda animar a futuras investigaciones.

El pasaje de la Guía de pecadores es el siguiente:

"Pues según esto ¿qué otra cosa es este mundo sino (como dijo un filósofo) un arca de trabajos, una escuela de vanidades, una plaza de engaños, un labirinto de errores, una cárcel de tinieblas, un camino de salteadores, una laguna cenagosa, y un mar de continuos movimientos? ¿Qué es este mundo sino tierra estéril, campo pedregoso, bosque lleno de espinas, prado verde y lleno de serpientes, jardín florido y sin fruto, rí de lágrimas, fuente de cuidados, dulce ponzoña, fábula compuesta, y frenesí deleitable? ¿Qué bienes hay en él que no sean falsos, y qué ma- 
les que no sean verdaderos? Su sosiego es congojoso, su seguridad sin fundamento, su miedo sin causa, sus trabajos sin fruto, sus lágrimas sin propósito, sus propósitos sin suceso, su esperanza vana, su alegría fingida, y su dolor verdadero"'.

A cualquier conocedor de la Tragicomedia de Calisto y Melibea puede evocarle inmediatamente el lamento de Pleberio, al conocer la muerte de su hija:

“ $;$ Oh mundo, mundo! (...) me pareces un laberinto de errores, un desierto espantable, una morada de fieras, juego de hombres que andan en corro, laguna llena de cieno, región llena de espinas, monte alto, campo pedregoso, prado lleno de serpientes, huerto florido y sin fruto, fuente de cuidados, río de lágrimas, mar de miserias, trabajo sin provecho, dulce ponzoña, vana esperanza, falsa alegría, verdadero dolor"2.

Pero fray Luis no se inspiró en La Celestina. Aunque la cronología de las obras no ofrece dificultad para que así hubiera sido, existían condicionamientos: la polémica levantada por la obra de Rojas, la censura, y la propia condición de fray Luis. De cualquier modo, no hace falta conjeturar sobre esa hipotética lectura ante la prueba evidente del texto de Petrarca. El fragmento se encuentra en las Epistolas familiares, y ya fue señalado hace años por Castro Guisasola ${ }^{3}$, y estudiado posteriormente por Deyermond ${ }^{4}$, como fuente de la Tragicomedia.

Las Epistolas familiares son una colección de cartas de Petrarca, escritas en latín a lo largo de su vida, y que versan sobre materias tan diversas como diversos son los destinatarios. Ya en 1347 Petrarca pensó reunirlas en un tomo, pero no llegó a realizarlo. Todavía el año siguiente -el aciago 1348, año de la peste y de la muerte de Lauraescribe varias, y lo mismo en años sucesivos. Será entre 1362 y 1365 , durante su estancia en Venecia, cuando Petrarca encargará al copista Giovanni Malpaghini la recopilación de las Familiares, en un corpus de 350 epístolas, agrupadas en 36 libros.

\footnotetext{
Primer libro. Tercera Parte. Capítulo XXVIII.

Auto XXI.

3 Castro Guisasola, F. Observaciones sobre las fuentes literarias de "La Celestina", Madrid, CSIC, 1924.

"Deyermond, A. The Petrarchan sources of "La Celestina”, London, 1961.
} 
Según probó Deyermond, Fernando de Rojas no utilizó una versión completa de Petrarca, sino una recopilación de varias obras, editada en Basilea en 1496, que en su testamento tituló Petrarca en latín, y que poseía un detallado índice temático ${ }^{5}$. Al consultar un ejemplar de esta edición en la Biblioteca Nacional de Madrid hemos podido observar que la última de las Epistolas familiares es precisamente ésta.

Este ejemplar, o cualquier otro semejante, pudo ser el que conoció fray Luis de Granada. La colocación, al final del último de los ocho libros, de la epístola que nos ocupa -la CXXII-, y su particular estilo y tono, fácilmente dejan eco en la memoria. La dedicatoria y el motivo constan al comienzo: "Ad Lombardum de Sirico, amicum suum: eidem praesentem vitam quam degimus describentis". La carta está escrita "Inter colles Euganeos, iij Kalendas Decembris", sin especificar año.

La epístola responde a una pregunta: "Quid mihi de hac vita quam degimus videatur interrogas. Neque immerito: Multi enim et varia de hac ipsa opiniones hominum sunt: meam brevibus accipe". Y expone a continuación su opinión por medio de una larga enumeración de metáforas, que es precisamente la que, con distinta finalidad, toman Fernando de Rojas y fray Luis:

"Videtur mihi vita haec dura quaedam arca laborum: palestra discriminum: scena fallaciarum: labyrinthus errorum: circulatorum ludus: desertum horribile: limosa palus: senticulosa regio: vallis hispida: mons praerruptus: caligantes speluncae: habitatio ferarum: terra infelix: campus lapidosus: vepricosum nemus: pratum herbidum plenumque serpentibus: florens hortus ac sterilis: fons curarum: fluvius lacrimarum: mare miseriarum: quies anxia: labor innefficax: conatus irritus: grata phrenesis: pondus infaustum: dulce virus: degener metus: inconsulta securitas: vana spes: ficta fabula: falsa letitia: verus dolor".

Aunque la enumeración continúa, la dejamos donde la abandonaron tanto Rojas como fray Luis de Granada.

Desconocemos de momento las circunstancias en que Petrarca escribió la epístola; el desengaño es tan patente que parece fruto de una

\footnotetext{
5 Principalium sententiarum ex Libris Francisci Petrarchae collectarum summaria Annotatio.
} 
reciente experiencia dolorosa. En este sentido no puede ser más apropiada la situación en que coloca el "préstamo" Fernando de Rojas: la desesperación de Pleberio ante Melibea muerta. Fray Luis, sin embargo, no lo pone en boca de un personaje: hace suyo el pensamiento negativo de Petrarca sobre esta vida, en fuerte contraste con lo que la vida es para aquellos que son amigos de Dios ${ }^{6}$. Este mundo, en definitiva, tiene cierta semejanza con el infierno:

"En lo cual podrás ver cuánta semejanza tiene este mundo con el infierno, porque si ninguna otra cosa es el infierno sino lugar de penas y culpas, ¿qué otra cosa abunda más en este mundo que ésta? (...) Pues si ninguna otra cosa es el infierno sino lugar de penas y culpas, ¿cómo no se llamará también en su manera este mundo infierno, pues en él hay tanto de lo uno y de lo otro?".

También la comparación estaba en Petrarca:

"Demonum regnum: luciferi principatus; Sic enim principem mundi huius veritas vocat: Vita demonum mendax: et exanimis".

El texto del Aretino ya era conocido por fray Luis antes de 1551 . Cuando en esa fecha es destinado a Portugal, tiene terminada la primera versión de la Guia de pecadores, que ha escrito en Badajoz, durante el poco tiempo que allí vivió. En esa primera redacción de la Guía -que se publica en Lisboa en 1556- aparece la cita ya completa, con la pequeña variante que supone una adición: "su ordē y cōcierto lleno đ cōfusiō", también tomada de las Familiares. En ninguna de las dos versiones menciona fray Luis la procedencia, supliendo el nombre de Petrarca por el genérico "un filósofo", (un sabio dice en 1556). Lo mismo hace cuando cita a Erasmo, al que suele llamar "un doctor". Es evidente que no le pareció oportuno incluir el nombre de estos dos autores al lado de las numerosísimas autoridades que aparecen en la Guia de pecadores. El texto de Petrarca que nos ocupa tampoco está

6 El pasaje está inserto en el capítulo "Contra los que recelan seguir el camino de la virtud por el amor del mundo". El punto que desarrolla inmediatamente después trata "De cómo la verdadera felicidad y descanso se halla en Dios y cómo es imposible hallarse en el mundo". 
recogido en sus recopilaciones de textos utilizables para la predicación o para la redacción de sus obras: Collectanea moralis philosophiae (Lisboa, 1571), o Silva locorum qui frequenter in concionibus occurrere solent (Salamanca, 1585).

Habría ahora que rastrear con más extensión y hondura la huella de Petrarca en la obra de fray Luis de Granada. A primera vista, en cuanto a préstamos se refiere, no parece haber más en la Guía. 